\title{
Land Cover Changes in the Malewa River Basin, Kenya
}

\author{
Musa Cheruiyot ${ }^{1}$, Gladys Gathuru ${ }^{2}$, James Koske ${ }^{3}$ and Reuben Soy ${ }^{4}$ \\ 1. WWF International, Nairobi 62440-00200, Kenya \\ 2. Department of Environmental Sciences, Kenyatta University, Nairobi 43844-00100, Kenya \\ 3. School of Environmental Studies, Kenyatta University, Nairobi 43844-00100, Kenya \\ 4. Directorate of Resource Surveys and Remote Sensing, Nairobi 47146-00100, Kenya
}

\begin{abstract}
Detection of land cover change helps in the understanding of how humans modify the natural environment. Modification is attributed to both restoration and degradation processes. Such information guides decisions on mitigating landscape degradation and advancing restoration. This study sets to determine land cover changes from 1973 to 2013 in the Malewa River Basin $\left(1,760 \mathrm{~km}^{2}\right)$ in central rift valley, Kenya. Satellite imageries from Landsat (Landsat Multispectral Scanner, 1973; Landsat TM (Thematic Mapper), 1986; ETM+ (Enhanced Thematic Mapper Plus), 2000; and SPOT, 2013) were analyzed using various imaging techniques available in ArcGIS 10.1 and ERDAS Imagine software. The results showed a cumulative growth of 25,617.0 ha (28.8\%) in area under cropland, an increase of 4,310.1 ha (11.3\%) in forestland and 688.0 ha (490.7\%) of wetland. There was a net decrease of $28,953.8$ ha $(72.2 \%)$ in the area under shrubland and $1,747.4$ ha $(19.2 \%)$ under grassland. The findings suggest that increased demand for arable land is mainly driven by food and income needs of the human population. This exerted enormous pressure particularly on shrublands and grassland. Increased forest cover suggests an improvement in forest restoration efforts during the last ten years. There is need to manage expansion into new arable areas by improving land productivity and tackling the drivers of land cover change.
\end{abstract}

Key words: Land cover change, degradation, restoration, change detection, imagery.

\section{Introduction}

The estimated global net loss of forests (about 7 to 11 million $\mathrm{km}^{2}$ ) since industrial period is attributed to land use activities [1, 2]. Globally agricultural expansion is one of the key drivers of land cover change and has shifted between regions over time. For example, in 2010, the global forest area was slightly over four billion hectares representing $31 \%$ of the total land area or an average of 0.6 ha per capita [3]. About ten years ago, forest transition processes either trended towards net deforestation (e.g. Brazil and Indonesia) or net afforestation (e.g. China and Chile) [4]. An effective transition to sustainable landscape change requires implementation of appropriate landscape planning approaches [5].

In Kenya, about $44.4 \%$ of the land area $(569,140$

Corresponding author: Musa Cheruiyot, MSc Education for Sustainability, research fields: land use and cover change, environmental flows, landscape restoration. $\mathrm{km}^{2}$ ) was under agriculture in 1973 compared to $48.5 \%$ in 2013. During the period, arable land increased from $6.15 \%$ (1.55 million ha) to $10.19 \%$ (2.57 million ha). From a national forest area of $47,240 \mathrm{~km}^{2}(8.3 \%$ of total land area) in 1990 , it declined to $35,570 \mathrm{~km}^{2}(6.25 \%)$ in 2000 and thereafter increased to $43,398 \mathrm{~km}^{2}(7.625 \%)$ in 2013 [6]. A study on selected forest areas (Mount Elgon, Taita Hills, Mau Forest Complex, Mount Marsabit) covering the period 1985 to 2010 showed mixed findings on land cover changes. The forest cover in the Mount Elgon area of Kenyan territory increased from 710 to $777 \mathrm{~km}^{2}$ and from 270 to $414 \mathrm{~km}^{2}$ in the Taita Hills area. The forest cover in the Mau Forest Complex decreased from 4,695 to $4,041 \mathrm{~km}^{2}$ during the same period. A similar trend was observed in the Mount Marsabit area where the cover reduced from 240.5 to $132 \mathrm{~km}^{2}$ [7].

Information on the current trends in forest cover change is limited particularly at landscape levels. It is 
therefore important to understand the current situation and use the information to inform the management of a particular landscape. In this way, landscape managers will be able to effectively apply landscape restoration measures for improved vegetation cover. This paper reports on a study designed to address the information gaps by determining land cover changes in one landscape, the Malewa River Basin in Kenya. The study covered the years 1973, 1986, 2000 and 2013.

\section{Material and Methods}

\subsection{Study Area}

The Malewa River Basin $\left(1,760 \mathrm{~km}^{2}\right)$ (Fig. 1) is located in Nakuru and Nyandarua counties of the Eastern Africa (Gregory) Rift Valley, Kenya. It is located at $36^{\circ} 05^{\prime} \mathrm{E}-36^{\circ} 42^{\prime} \mathrm{E}$ longitudes and $00^{\circ} 07^{\prime}$ S- $00^{\circ} 45^{\prime} \mathrm{S}$ latitudes. The annual flow of the Malewa River is estimated at 153 million $\mathrm{m}^{3}$ [8]. The area has complex soil characteristics, influenced by extensive relief variation, volcanic activity and underlying bedrocks [9]. Soils have largely been developed from lacustrine deposits, volcanic and lacustrine-volcanic formations $[9,10]$. These soils are prone to the effects of erosion and compaction. Soil degradation is largely due to wind and water erosion, sealing and compaction [11]. The fragile nature of the place and various human activities is thought to accelerate land degradation in the west and south of the basin [12]. Land cover consists mainly of forest, scrub/bush-land/native, bare/range and brush/moorland, grassland/scrubland, and agricultural land (small intensive/sparse). The upper catchment is dominated by forests and cropland with maize, wheat, potatoes and vegetables being grown. Livestock grazing is predominant in the lower catchment [13].

\subsection{Land Cover Change Detection}

Satellite imagery from Landsat MSS (Multi-Spectral Scanner) (1973), Landsat TM (Thematic Mapper) (1986) and ETM+ (Enhanced
Thematic Mapper Plus) (2000) was obtained from the Landsat database (Landsat.org orthorectified archives) [14]. SPOT image of 2013 was acquired from Astrium courtesy of World Wide Fund (WWF) for Nature Kenya office. The image characteristics, sources and acquisition dates are indicated in Table 1.

Landsat images were geo-processed using ERDAS Imagine 2015 and ArcGIS 10.1 software. A pre-processed SPOT 2013 image was used. UTM (Universal Transverse Mercator) Projection Zone 37N and WGS 84 Datum were adopted in the registration procedures. DeltaCue was used to perform image registration. AutoSync was used to automatically generate control points and co-register the image pair [15]. One image was selected as a reference (or "master") while the other ("slave") was transformed to match the "master" [16]. Using DeltaCue software, image differencing technique was applied to detect change and/or no change by analyzing intensity differences. This technique produces a change image for which a change/no change threshold must be established. In a case where no change has occurred, the difference between two images is a zero mean noise distribution [15].

In this image differencing technique, two registered images of the same area but obtained from two different time periods ( $t_{1}$ and $\left.t_{2}\right)$ are subtracted pixel-wise [17]. The formula is expressed as in Eq. (1).

$$
l_{d}(x, y)=l_{1}(x, y)-l_{2}(x, y)
$$

where: $l_{1}$ and $l_{2}$ are the images obtained from time $t_{1}$ and $t_{2} ;(\mathrm{x}, \mathrm{y})$ are the coordinates of the pixels; $l_{d}$ is the resulting image and represents the intensity difference of $l_{1}$ and $l_{2}$.

Image segmentation [18] is a process used to partition an image into homogenous groups except that the union of two adjacent regions should not be homogenous [19]. A multilevel image was converted into a binary image. A proper threshold was chosen to divide image pixels into several regions and separate objects from background [20]. 


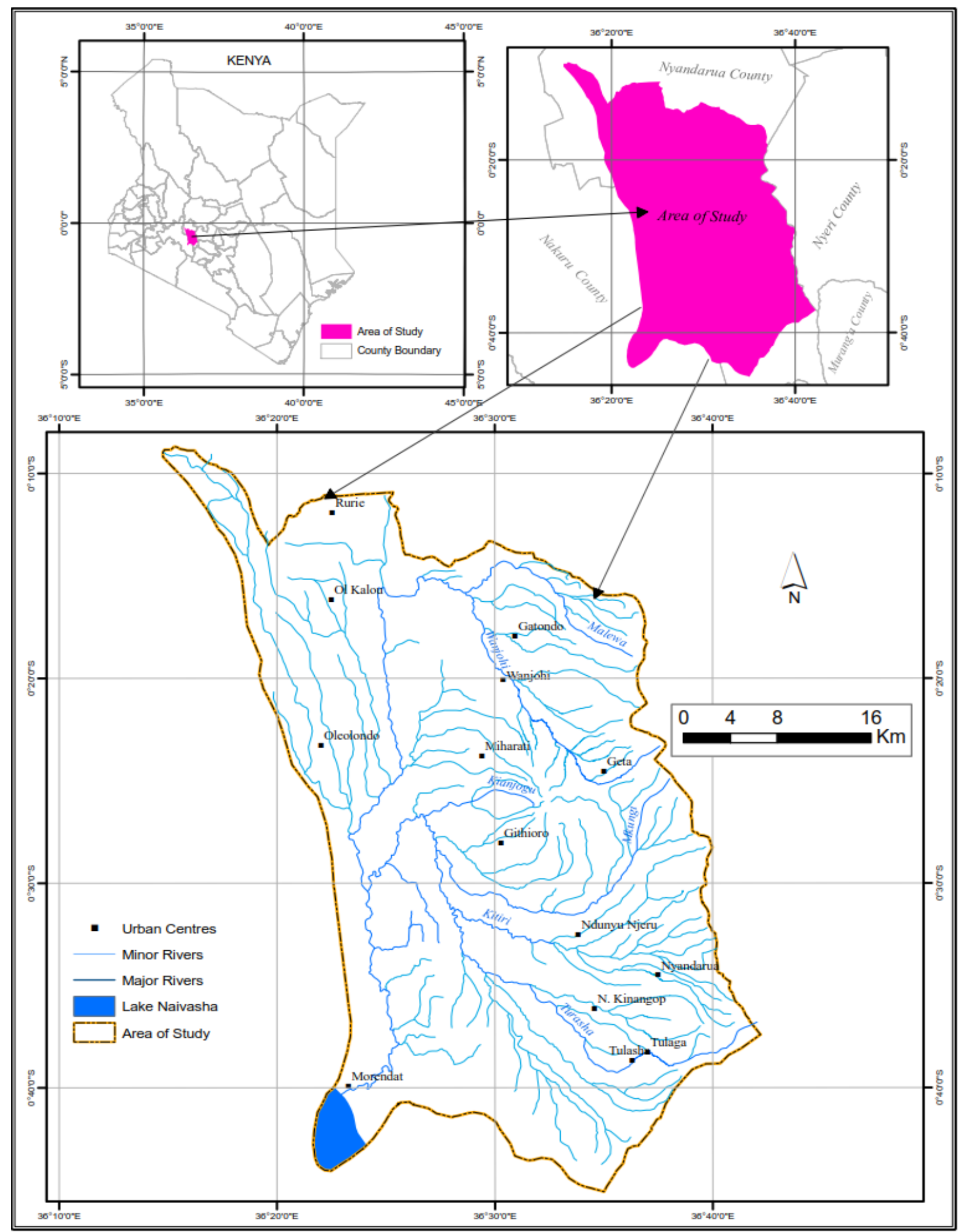

Fig. 1 Map of the study area. 
Table 1 Image characteristics, sources and acquisition dates.

\begin{tabular}{lllll}
\hline Year & Image & Spatial resolution & Dates & Source \\
\hline 1973 & P181R60 & $28.5 \mathrm{~m}$ & 31.1 .1973 & NASA [21] \\
1975 & P181R60 & $28.5 \mathrm{~m}$ & 31.1 .1975 & NASA [21] \\
1986 & P168R60 & $28.5 \mathrm{~m}$ & 25.2 .1987 & NASA [21] \\
& P168R61 & $28.5 \mathrm{~m}$ & 28.1 .1986 & NASA [21] \\
2000 & P168R60 & $28.5 \mathrm{~m}$ & 27.1 .2000 & NASA [21] \\
& P168R61 & $28.5 \mathrm{~m}$ & 21.2 .2000 & NASA [21] \\
2013 & SPOT 2 & $2.5 \mathrm{~m}$ & 23.5 .2013 & Astrium, Toulouse France \\
\hline
\end{tabular}

ERDAS Imagine 2015 was used to perform image processing and enhancement. Band combinations were performed to obtain color composites for the three sets of geo-referenced Landsat data. These are bands 4, 3, 2 for TM and ETM+ images which represent red, green and blue and Bands 3, 2, 1 for the MSS. Image interpretation techniques were applied on false colour composite data. An object-based classification methodology of remote sensing data was applied, and this enabled the comparison of data across the assessment years. A supervised maximum likelihood classification approach was used to classify single and groups of pixels representing objects. Using supervised classification, images were classified by analyzing the spectral signatures obtained from training samples. The training samples that represent the classes required were created using image classification toolbar. A signature file was then created from the training samples. Multivariate classification tools were used to classify the images.

The user value of data resulting from image analysis is determined through accuracy assessment [22]. In this process, reference pixels are randomly selected [23]. Accuracy assessment of the 2013 results was done using 2014 Google Earth image. Google Earth image was used because of its relative accuracy, and it was assumed to compare well with 2013 image. A classified image of 2013 was verified with Google Earth image by running a confusion matrix using user classification and reference image. After the image was classified, 150 random points were generated in ArcMap. The class of each random point was then identified from Google Earth image. Individual and overall accuracy was calculated. The measure of agreement between model prediction and reality was determined using Kappa $\kappa$ [23].

\subsection{Land Cover Classes}

Based on a classification scheme [24], six distinct classes were generated. These are cropland (horticulture and rainfed crops), forestland (natural forest, woodlot and forest plantation), wetland (open waters and swamps/marshes), shrubland, grassland and settlement. Due to the low spatial resolution of the images, settlement, woodlands and plantations were not visualized in the Landsat series. Interpreted raster was converted into polygons using conversion tool in ERDAS Imagine. The geometry tool in ArcGIS was used to calculate coordinate values, lengths and areas. Small polygons which never met the minimum mappable area were eliminated through merging.

\subsection{Vegetation Analysis}

The annual rate of change of forest to other land cover classes was calculated using the Puyravaud equation (Eq. (2)) [25]. This equation is expressed as follows:

$$
r=\frac{1}{\left(t_{2}-t_{1}\right)} \operatorname{In}\left(\frac{A_{2}}{A_{1}}\right)
$$

where: $r$ is annual rate of change; $A_{1}$ and $A_{2}$ are the forest cover (ha) at time $t_{1}$ and $t_{2}$ (years) respectively.

Vegetation health was detected using the NDVI (Normalized Difference Vegetation Index) algorithm. The red reflectance values were subtracted from the near-infrared and divided by the sum of the 
near-infrared and red bands [26] (Eq. (3)). NDVI ranges between -1.0 and 1.0. High positive values represent greenness and therefore high intensity of vegetation reflectance. Values closer to zero represent rock and bare soil. Clouds, water and snow have negative values.

$$
\mathrm{NDVI}=\frac{\mathrm{IR}-\mathrm{R}}{\mathrm{IR}+\mathrm{R}}
$$

where: $I R=$ pixel values from the infrared band; $R=$ pixel values from the red band [26].

Three hundred and thirty one (331) randomly generated NDVI values were extracted using the algorithm. To use these data for assessment of mean, all values less than zero were discarded to only reflect those indications of vegetation.

Image differencing technique was applied to detect overall change in vegetation between 1973 and 2013. To do so, Landsat MSS images of 1973 and 1975 were downloaded from glovis.usgs.gov [21]. Using ERDAS Imagine 2015, the images were mosaicked by histogram matching colour corrections and overlap areas matching methods. The mosaicked output image was clipped using the shapefile of the subset boundary to obtain the area of interest. As well, SPOT 2013 image previously with a spatial resolution of $28.5 \mathrm{~m}$ was resampled to $60 \mathrm{~m}$ resolution using a default nearest neighbour method. Final Landsat MSS subset image and SPOT 2013 image both with $60 \mathrm{~m}$ spatial resolution were subjected to Zonal Change Image Difference function in ERDAS Imagine 2015. The differencing was then performed to detect vegetation change. The image difference output was obtained after running the image difference function.

Five classes of vegetation changes were identified. As such, results were interpreted as: areas of increased and decreased vegetation, areas with some increase and decrease, and others which had no vegetation change detected. The areas of the five classes were calculated using ArcMap field calculator tool. The resultant values were exported to Microsoft Excel 2016 as dBase file. Microsoft Excel was used to calculate the total area and also to express the same area values to percentage. The total area of the image highlight was compared to total area of the outline boundary which was used to subset the image. Finally, using the ArcMap version 10.2.2 the output map was created depicting the vegetation change.

\section{Results and Discussion}

\subsection{Land Cover Transitions (1973-2013)}

Image analysis of the study area demonstrated that land cover changes had occurred during the three epochs assessed: 1973-1986, 1986-2000 and 2000-2013 as shown in the land cover maps generated for the years 1973, 1986, 2000 and 2013 (Figs. 2-5). The areas under cropland increased cumulatively from 1973 to 2013. Forestland decreased until 2000, and thereafter increased. Grassland was generally low in coverage except for 1986 while shrubland fluctuated with an overall decline (Fig. 6). There was an overall growth of $28.8 \%$ in area under cropland, $11.3 \%$ in forestland and $490.7 \%$ in wetland. A net decline was observed in area under shrubland (-72.2\%) and grassland (-19.2\%). Area under settlement was detected at 86.1 ha in 2013.

The absolute and percentage changes in land cover for the different periods assessed are shown in Table 2. The area under cropland had an absolute growth of 5,614 ha between 1973 and 1986; 8,174 ha between 1986 and 2000 and 11,819 ha during 2000-2013. Cropland had a cumulative increase of 25,617 ha by 2013. This represented $28.8 \%$ growth that could be accounted by gain from shrubland $(23,235.7 \mathrm{ha})$ and grassland (4,810 ha) but a net loss to forest $(2,344.0$ ha), settlement (50.6 ha) and wetland (34.2 ha). Factors such as population pressure and the need for food and income seem to drive the changes of land use particularly affecting shrubland, grassland and forestland.

There was a net loss in forestland during the 1973-1986 (2,650 ha) and 1986-2000 (1,808 ha) periods. However, a positive trend was observed from 


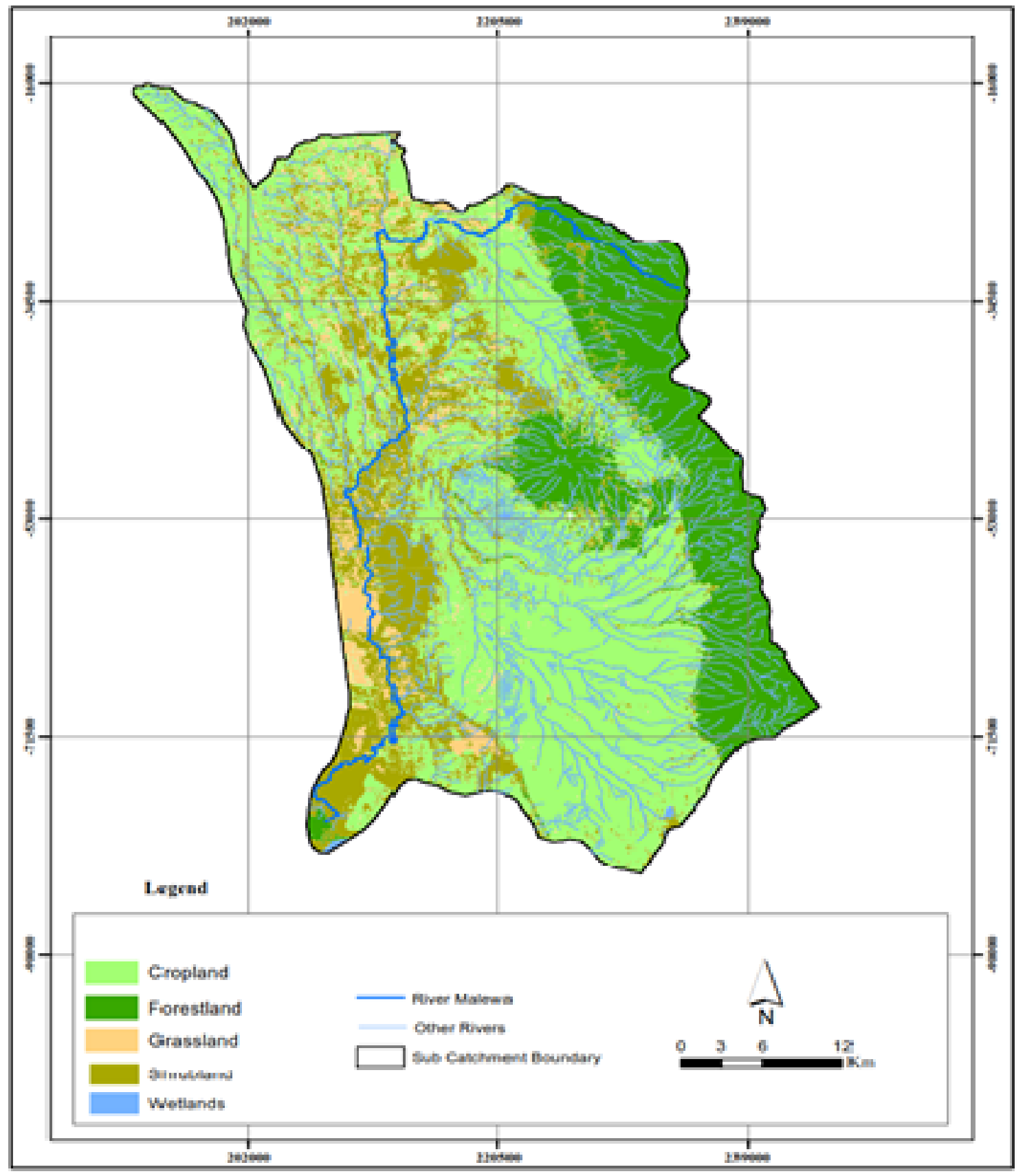

Fig. 2 Land cover map (1973). 


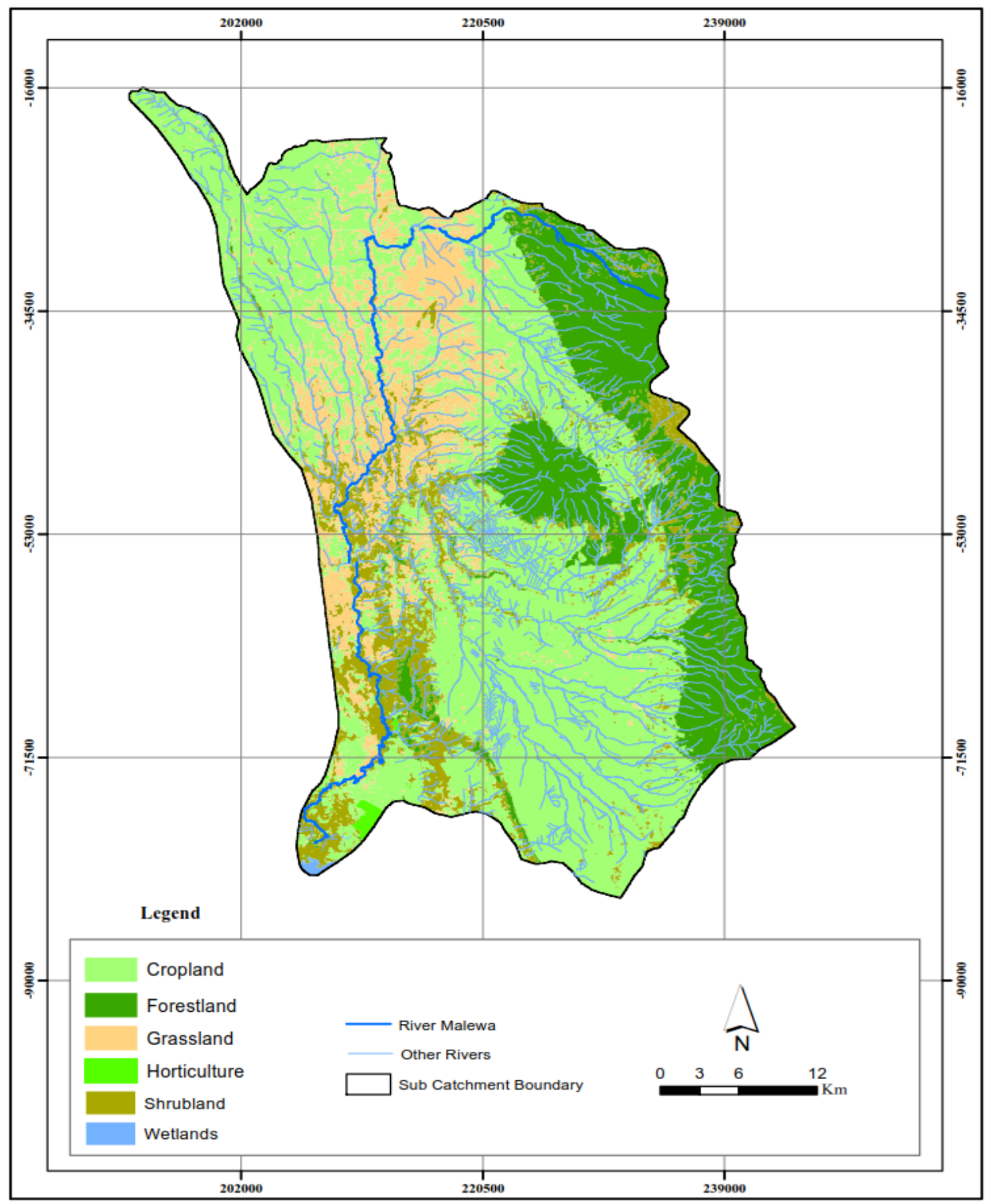

Fig. 3 Land cover map (1986). 


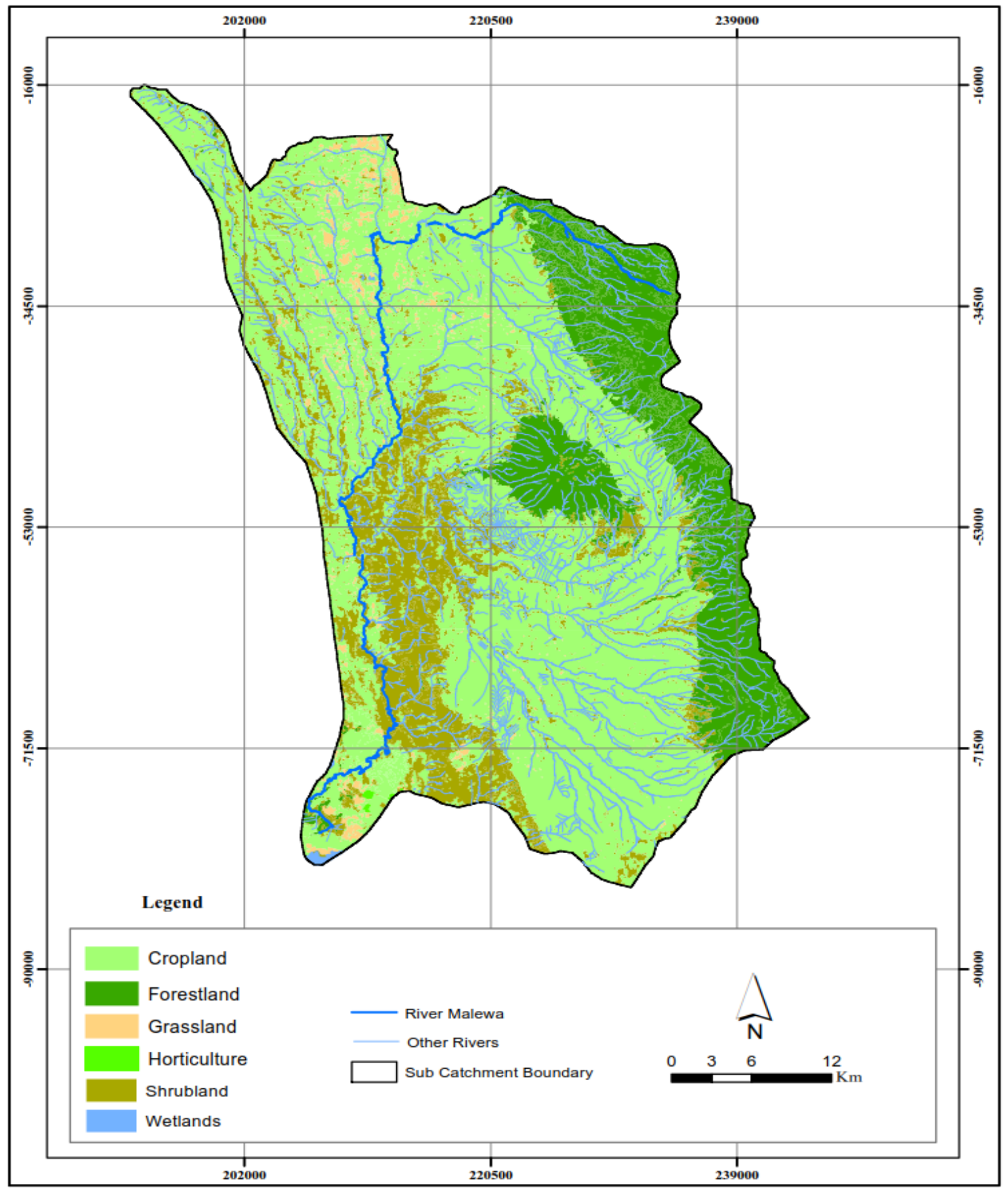

Fig. 4 Land cover map (2000). 


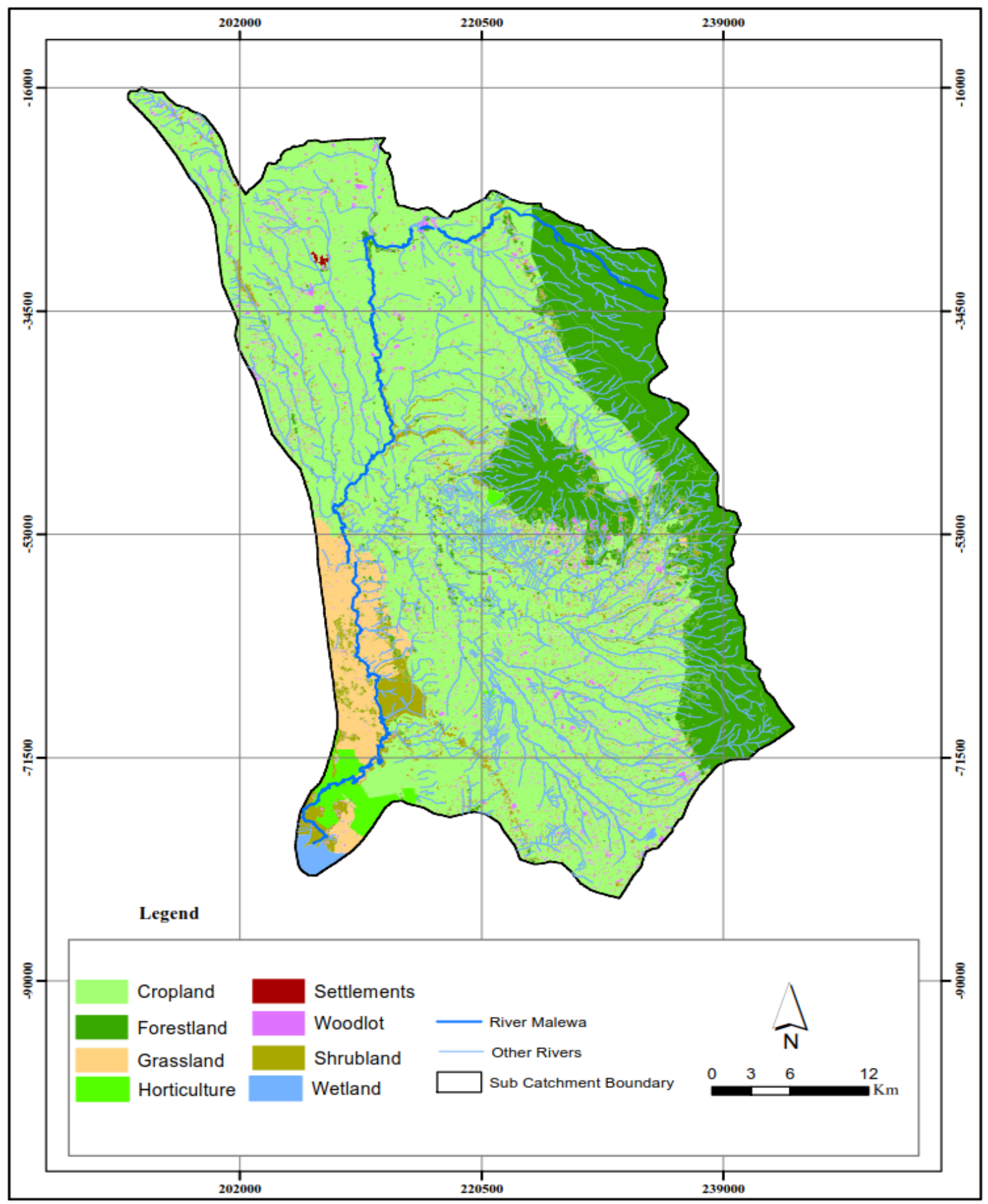

Fig. 5 Land cover map (2013). 


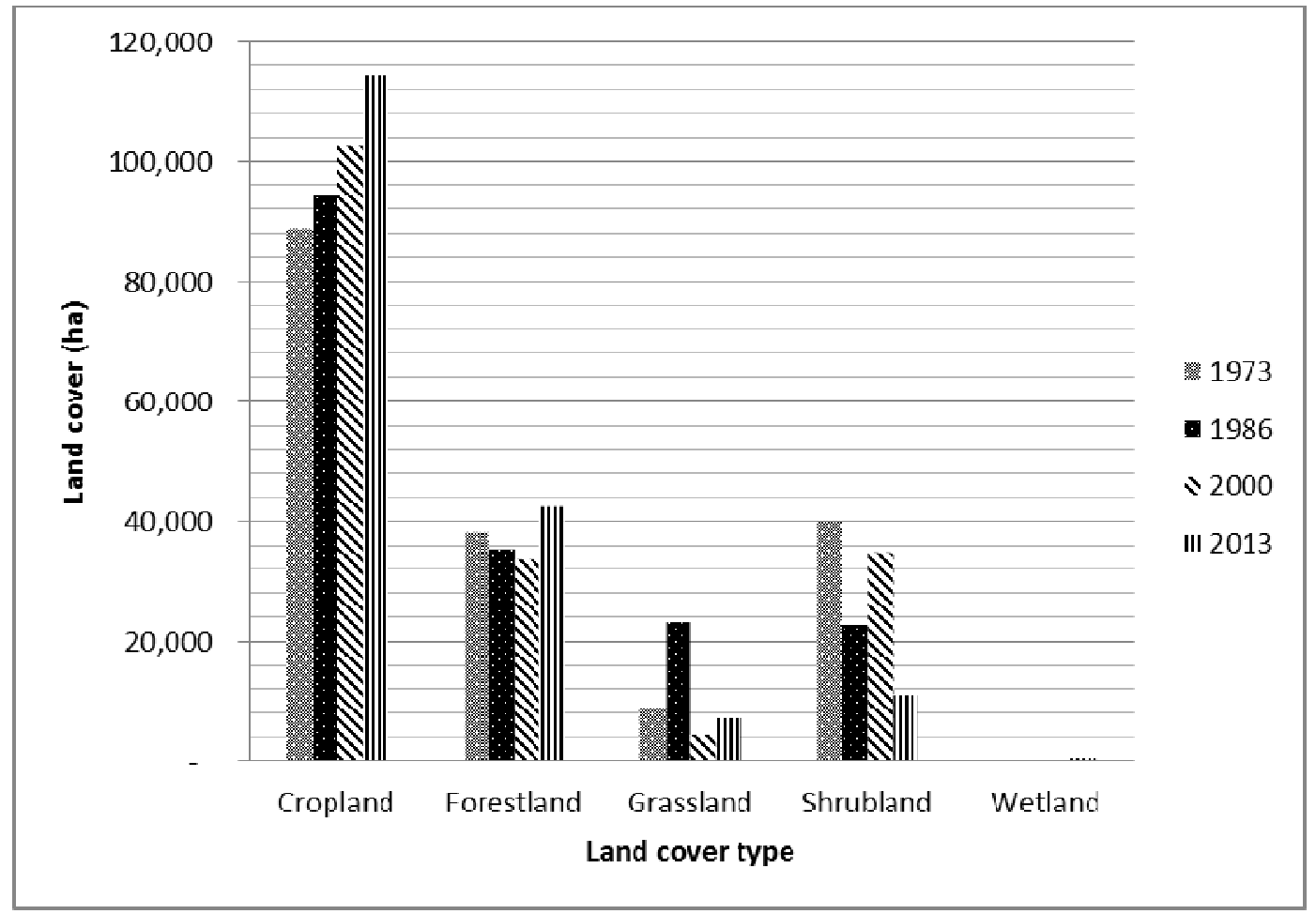

Fig. 6 Acreage by land cover types.

Table 2 Absolute and percentage changes in land cover (1973-2013).

\begin{tabular}{|c|c|c|c|c|c|}
\hline \multirow{2}{*}{ Parameter } & \multicolumn{5}{|c|}{ Land cover change } \\
\hline & Cropland & Forestland & Grassland & Shrubland & Wetland \\
\hline Acreage in 1973 (ha) & $88,834.9$ & $38,221.1$ & $9,124.1$ & 40,095 & 140.2 \\
\hline Absolute \& $\%$ change & $\begin{array}{l}5,614.4 \\
(6.3)\end{array}$ & $\begin{array}{l}(2,650.2) \\
(-6.9)\end{array}$ & $\begin{array}{l}14,200.3 \\
(155.6)\end{array}$ & $\begin{array}{l}(17,359.0) \\
(-43.3)\end{array}$ & $\begin{array}{l}194.5 \\
(138.7)\end{array}$ \\
\hline Acreage in 1986 (ha) & $94,430.6$ & $35,556.7$ & $23,321.8$ & $22,724.9$ & 334.3 \\
\hline Absolute \& $\%$ change & $\begin{array}{l}8,174.3 \\
(8.7)\end{array}$ & $\begin{array}{l}(1,807.8) \\
(-5.1)\end{array}$ & $\begin{array}{l}(18,696.8) \\
(-80.2)\end{array}$ & $\begin{array}{l}12,373.1 \\
(54.4)\end{array}$ & $\begin{array}{l}(42.8) \\
(-12.8)\end{array}$ \\
\hline Acreage in 2000 (ha) & $102,604.9$ & $33,748.9$ & $4,625.0$ & $35,098.0$ & 291.5 \\
\hline Absolute \& $\%$ change & $\begin{array}{l}11,819.1 \\
(11.5)\end{array}$ & $\begin{array}{l}8,767.4 \\
(26.0)\end{array}$ & $\begin{array}{l}2,748.4 \\
(59.4)\end{array}$ & $\begin{array}{l}(23,956.0) \\
(-68.3)\end{array}$ & $\begin{array}{l}535.0 \\
(183.5)\end{array}$ \\
\hline Acreage in 2013 (ha) & $114,451.9$ & $42,531.2$ & $7,376.7$ & $11,141.1$ & 828.2 \\
\hline Absolute \& $\%$ change & $\begin{array}{l}25,616.9 \\
(28.8)\end{array}$ & $\begin{array}{l}4,310.3 \\
(11.3)\end{array}$ & $\begin{array}{l}(1,747.5) \\
(-19.2)\end{array}$ & $\begin{array}{l}(28,953.8) \\
(-72.2)\end{array}$ & $\begin{array}{l}688.0 \\
(490.4)\end{array}$ \\
\hline
\end{tabular}

2000 with a dramatic increase of 8,767 ha. Overall, forestland had a net growth of 4,310.1 ha from 1973-2013. This growth was due to gain from cropland (2,344 ha), shrubland (2,047.7 ha) and grassland (278.8 ha), but a loss to wetland (360.2 ha). Forestland declined marginally until 2000, thereafter increasing past the 1973 baseline. Intense afforestation from 2000 may have affected the substantial gains of more than 8,700 ha in forestland. Overall the net positive change in forests is likely to be due to abandonment of cropland and shrubland that paved way for either natural regeneration or intensified afforestation.

Grasslands had substantial fluctuations in area with an increase of 14,200 ha between 1973-1986, subsequent decline of 18,697 ha (1986-2000) and increase of 2,748 ha (2000-2013). However, overall there was a net decrease of 1,747.4 ha (19.2\%) for the entire study period. This was due to a net gain from shrubland $(3,357.7 \mathrm{ha})$ but a loss to cropland $(4,810$ 
ha), forestland (278.8 ha), settlement (16.2 ha) and wetlands ( 0.2 ha). Grassland seems to be vulnerable to rapid changes either from conversion from grassland to shrubland or grassland to cropland. These may be due to clearance to pave way for livestock use or cultivation after years of rejuvenation.

Shrubland substantially lost to other land cover classes by 17,359 ha (1972-1986), increased by 12,373 ha (1986-2000) and declined by 23,956 ha by 2013. Overall shrubland lost about 28,954 ha during the entire period. This dramatic change was due to losses to cropland $(23,235.7 \mathrm{ha})$, grassland $(3,357.7$ ha), forestland (2,047.7 ha), shrubland (293.4 ha) and wetlands (19.3 ha). Shift to crop production was the likely main driver of shrubland drastic loss. The transition to grassland for livestock use and also to forest land due to regeneration and afforestation efforts may have influenced the changes. The changes in rainfall patterns may have also influenced the increase particularly during 1986-2000 period.

Wetlands expanded by 195 ha (1973-1986), marginally declined (43 ha) (1986-2000) and thereafter increased by 535 ha (2000-2013). Overall, wetlands had a net increase of 688 ha $(490.7 \%)$ due to a gain from forestland (360.2 ha), shrubland (293.4 ha), cropland (34.2 ha) and grassland (0.2 ha). The likely reasons for wetland increase could have been development of dam infrastructure and changes in rainfall patterns. The above changes have been summarized below (Fig. 7).

The land cover changes over 1973-1986 period (Table 2) show similarity with findings from the Bale Mountains ecoregion in Ethiopia. There was a forest loss and a gain to cropland, with farmland and urban settlement expansion as major drivers of change. A net forest loss of 123,751 ha and a gain to farmland of 292,294 ha were reported [27]. Increased built-up area and reduced agricultural area, water bodies and forest area have also been reported elsewhere [28]. There is reported correlation between land holding, land use and forest cover distribution [29]. The results from this study however differ from that of Ouedraogo, et al. [30] covering 1990, 2000 and 2013. The study in Cassou District, Ziro Province of southern Burkina Faso showed high net changes in shrub (39\%) and woodlands $(-37 \%)$. There was a weak net positive change for cropland (only $2 \%$ ), such that this area remained almost unchanged. There was a decline in wooded savannah and exponential increase in shrub savannah. This suggested a movement towards agricultural intensification. Elsewhere in Karkloof catchment, South Africa, change of land cover from grassland to commercial timber plantation and commercial cropping has been reported. However, notable changes to subsistence cropping have been minimal. This was attributed to changes in patterns of land ownership from private to corporate [31].

The results for 1986-2000 suggest that agricultural expansion affected grassland, forestland and wetland areas. Abandonment of exhausted lands likely allowed for succession into shrubland. Some forests emerged due to regeneration and possibly following intensified afforestation. Wetlands decreased possibly due to reduced moisture conditions and succession to grassland, shrubland and forest. When the land is exhausted, it is quickly transitioned into grassland and where possible wetlands. In the longer term, shrubland and grassland changed into farmlands. The data seem to suggest that overall some sections of cropland ended being forested. Cultivation continued to be a major pressure, taking an upward trend. Grassland suffered heavy losses, giving way to crops while shrubland had a tremendous growth suggesting land had been left fallow and thereafter changed to other uses such as grazing and forest.

Except for studies that cover parts of the Lake Naivasha Basin, there was no specific comparative analysis for the study area for this period. However, findings from a study of the entire Lake Naivasha basin (1986-2007) showed that except for cropland and built-up area, areas under forests, woodland, grassland and shrubland suffered a declining trend in 


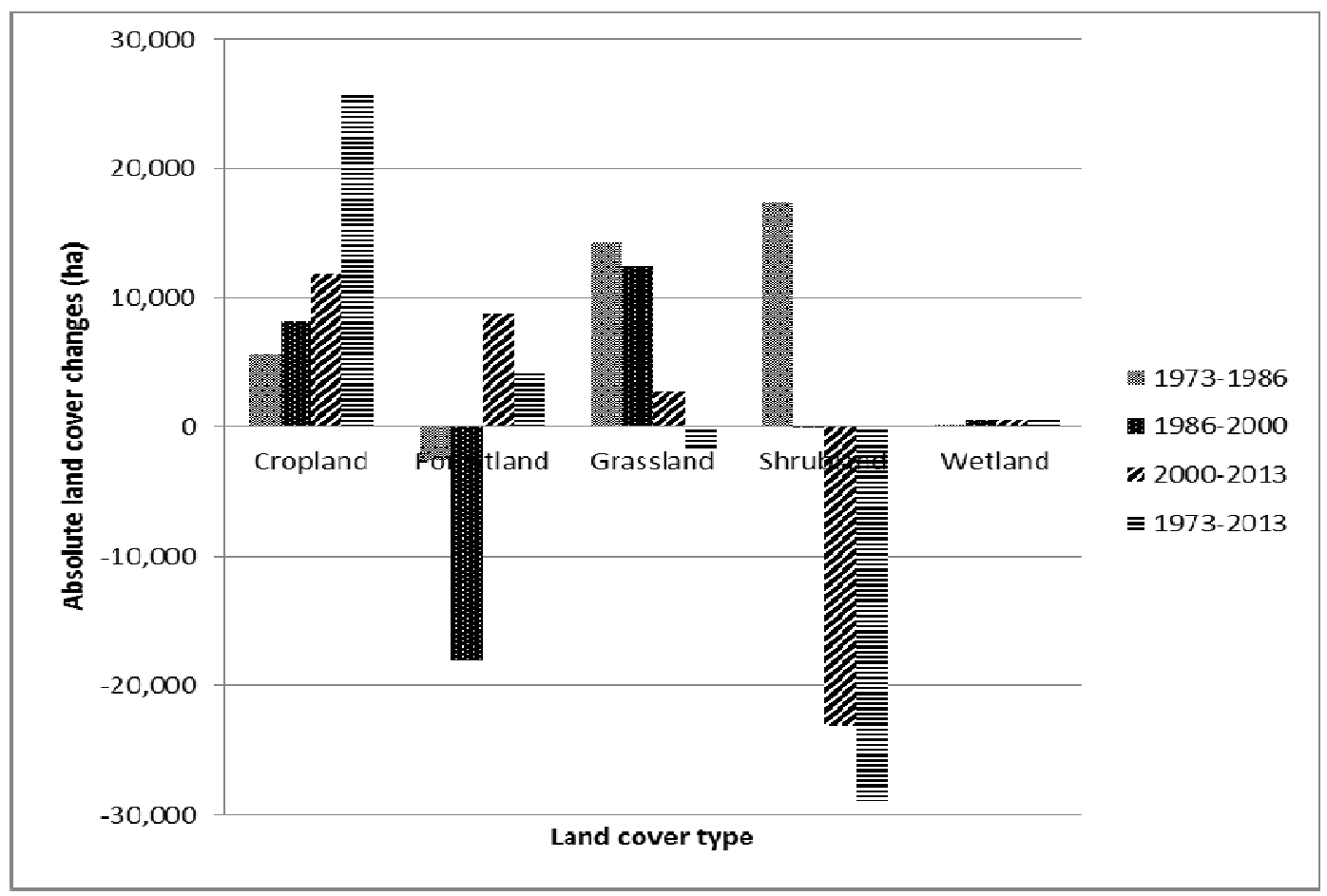

Fig. 7 Absolute land cover changes.

rates and magnitude of change [32]. The results are also similar to what was found in Ref. [33] in a study area (about $1,650 \mathrm{~km}^{2}$ ) within the Lake Naivasha Basin (1986-2000). The findings showed that dense vegetation decreased by 5,610 ha (15.4\%), grassland by 5,870 ha $(8.43 \%)$, wetlands decreased by 25.3 ha $(46.3 \%)$ and farmlands increased by 10,000 ha (31.4\%). However, these results differ with findings from Puer and Simao Counties, China. It showed that forest or shrubland and barren land decreased by about $6 \%$ and $23 \%$ respectively from 1990-1999, and subsequent increased in farmland, settlement and wetlands by $19 \%, 4 \%$ and $7 \%$ respectively. Agricultural land increased with high altitude attributed to tea growing [34].

The results for 2000-2013 show that all the land uses except shrubland had net positive changes (Table 2). There were no comparative study findings available for these reference years. Elsewhere, in the Usangu catchment, changes observed in 2000, 2006 and 2013 were attributed to annual rainfall, population density and distance from road networks. Terrain and edaphic factors (elevation, slope and soil types) influenced its distribution. However, human activities strongly influenced the land use and land cover changes and distribution [35]. About $75 \%$ of the land use changes (2001 to 2010) experienced in Northern Laos were attributed to socio-economic factors. These were upland rice growing, rubber plantation, maize farms and farm location [36]. In the Volta Basin, Ghana, biophysical and social variables explained cropland change. Market related variables were linked to response to changing economic opportunities [37].

Reporting by Petit, et al. [38] of a $44 \%$ change in land cover is consistent with the finding of this study, although the magnitude of change differs. Other findings are mixed, for example Ouedraogo, et al. [30] suggest drastic changes in shrubland (39\% increase) and woodland savannahs ( $37 \%$ decrease), and a weak positive change in cropland (2\%), that does not compare with the $29 \%$ cropland change in the Malewa area. Agricultural intensification has been suggested as a likely reason for the marginal growth in cropland. A reduction in agricultural land, water bodies and 
forest area [28] also differs with the findings of this study. In Azerbaijan, land cover changes (2014-2015) showed increase in areas under agriculture, built-up area and forest, but a decline in area under grassland [39]. In Hawalbagh block (India), changes observed (1990-2010) indicate an increase in area under vegetation and settlement, and decline in area under agriculture, barren land and water body [40]. In Lugari District in Kenya, an increase in human population and activities significantly related to changes in land use practices attributed to land degradation. Notable were cultivation and grazing as significant drivers of the change [41]. The Malewa study results are consistent with Zacharia, et al. [42] who found significant negative land cover changes had occurred (1989-2010) around Lake Olbolosat in central Kenya. The forest area reduced by about $30 \%$, farmlands increased by $31 \%$ (due to commercial and subsistence agriculture); flood plains reduced by $26 \%$ and built up areas increased by $33 \%$. The overall change was a reduction of the size of the lake by $68 \%$.

\subsection{Vegetation Change}

Area land cover change is scant on details of specific short term changes and vegetative intensity. The annual rates of change of forest cover to other land use types were estimated at $0.0055 \%$ (1973-1986), $0.0037 \%$ (1986-2000) and $0.0042 \%$ (2000-2013). Overall the annual rate of change between 1973 and 2013 was $0.0044 \%$. From a visual observation (Fig. 8), major negative changes occurred at the northern (Ol Kalou, Rurie), north-eastern (Gatondo, Wanjohi), eastern (Geta), south eastern (Ndunyu Njeru, North Kinangop, Tulaga) and central (Githioro) parts of the catchment. However, the south western (Lower Malewa) and north western parts had limited change. Based on a magnitude change of $10 \%$ vegetation increase/decrease and no change criteria, $64.8 \%$ of the area assessed had experienced a net decrease in vegetation, $34.4 \%$ had a net increase and only $0.8 \%$ showed no change (Table 3 ).
The mean NDVI values observed for the years 1973, 1986, 2000 and 2013 are shown in Fig. 9. The NDVI values showed that vegetation health deteriorated from 1973 and was at its low around 2000. Vegetation intensity values however rose to a near 1973 state in 2013. Virtually all areas experienced a net change in vegetation cover at one point in time. The area is predominantly an agricultural landscape with NDVI values showing average values of less than 0.27.

Vegetation intensity has been suppressed by the land cover changes. The study area is predominantly cropland, forestland and shrubland. An ever increasing acreage under cropland for the entire study period implies that other land cover areas are losing out particularly shrubland, forestland and grassland. This is particularly so for forestland in 1986-2000, shrubland in 2000-2013 and overall losses on shrubland over the entire three decades. The data suggest gains in forest cover closely matching the 1973 baseline conditions perhaps due to intensified afforestation.

Overall, while the annual rate of change of forest to other land uses was low, there is concern that vegetation cover was declining much more than increasing. Virtually all areas had experienced change in vegetation (Fig. 6), and the results also seem to suggest that this area is increasingly transitioning into an agro-ecological landscape. The low NDVI values generally show that this area is becoming a predominantly human modified landscape. The low NDVI values as compared for example to the Mau forest complex, Kenya [43] attest to this trend. This implies that most of the areas are experiencing intensified pressure from human activities.

\section{Conclusions}

This study was designed to bridge information gaps on land cover changes in the study area, particularly to inform landscape managers on appropriate responses. In absolute terms, it is evident that drastic land cover changes both positive and negative were witnessed 


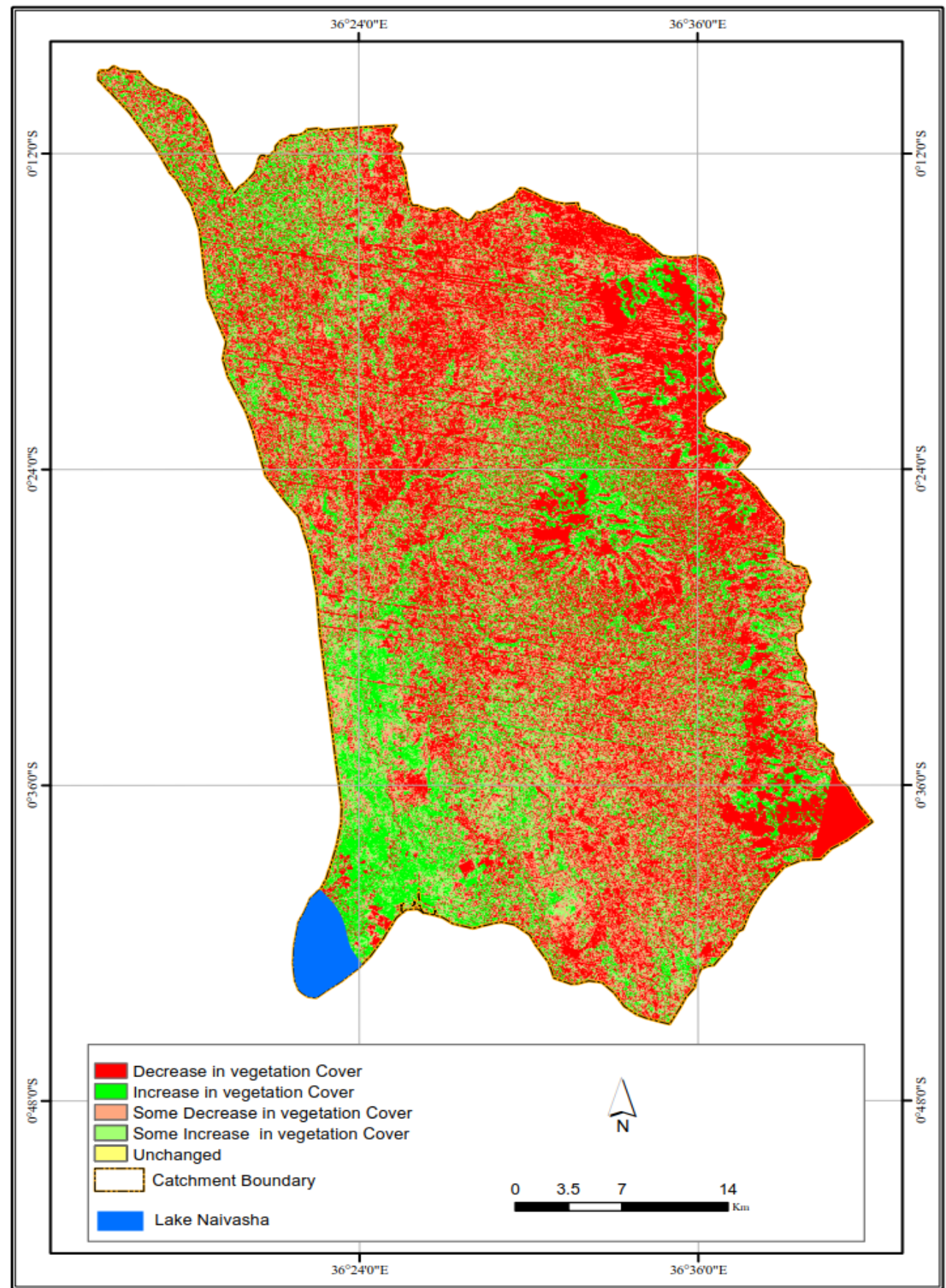

Fig. 8 Vegetation changes in the study area.

Table 3 Cumulative changes in vegetation (1973-2013).

\begin{tabular}{lll}
\hline Vegetation change & Area change (ha) & \% Change \\
\hline Decrease in vegetation cover by $10 \%$ & $75,075.5$ & 42.6 \\
Some decrease in vegetation cover by $10 \%$ & $39,044.5$ & 22.2 \\
Unchanged & $1,458.4$ & 0.8 \\
Some increase in vegetation cover by $10 \%$ & $26,676.0$ & 15.1 \\
Increase in vegetation cover by $10 \%$ & $33,964.9$ & 19.3 \\
Total area & $176,219.3$ & 100.0 \\
\hline
\end{tabular}




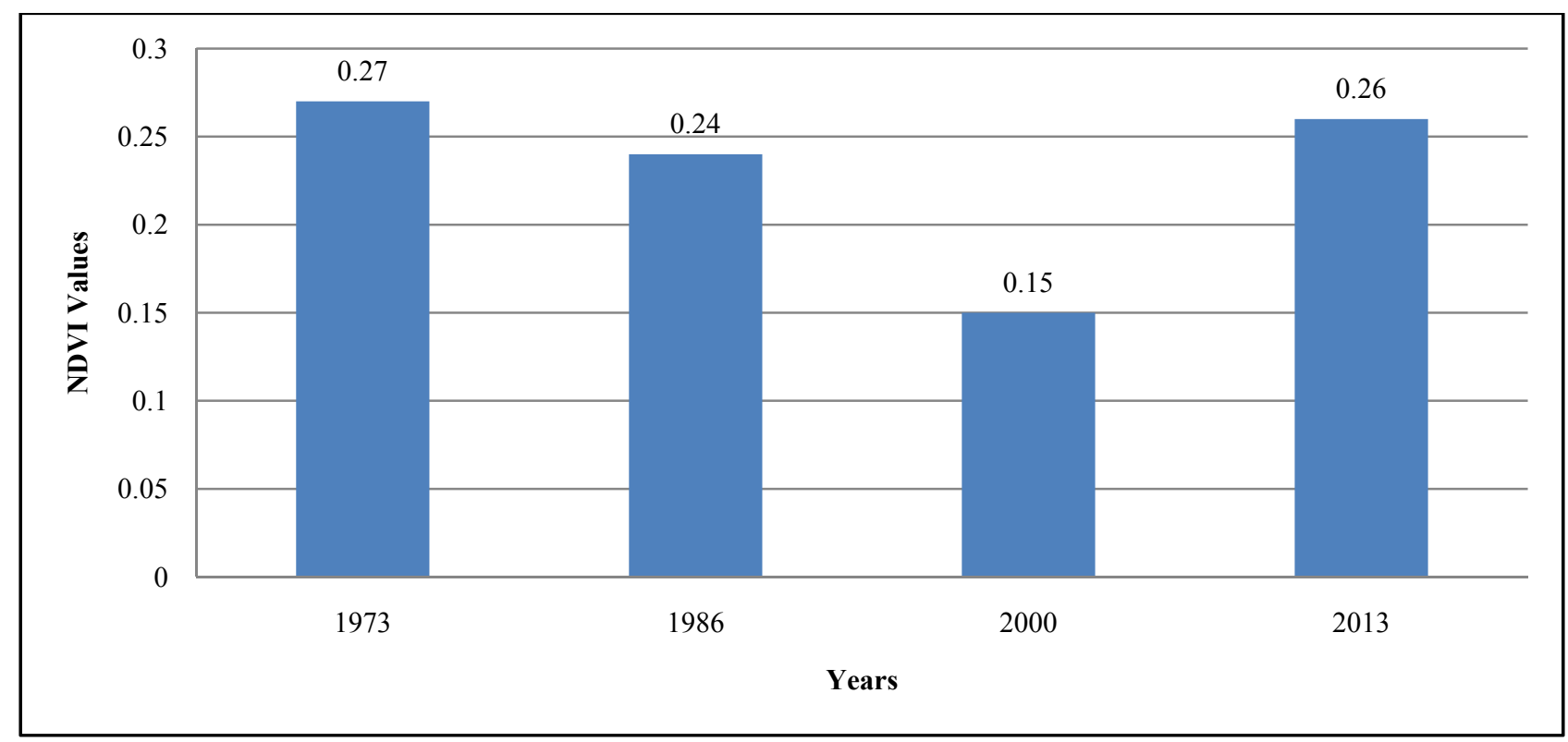

Fig. 9 Mean NDVI values (1973, 1986, 2000 and 2013).

affecting cropland, shrubland, grassland and forestland.. The increasing trends in areas under cropland and declining states in shrubland are an area of concern. This trend is likely to continue unless some mitigation measures are instituted. Overall over the 40 year assessment period, a $28.8 \%$ growth in cropland suggests increased demand for arable land for food production and income. Conversion of grassland and shrubland for agriculture (crops and livestock production) presents the greatest threat to land cover change in this area. An increased growth of 4,310.1 ha (11.3\%) in forest cover, surpassing the 1973 baseline suggests great potential to reach the initial state before settlement schemes were established in the area. Despite the losses in shrubland and grassland, the findings seem to suggest significant progress in afforestation with growth in area under forests. Interpreted, multiple transitions do occur due to different land cover change processes including abandonment, restoration, succession, reclamation among others. Due to the large time span of epochs used (roughly ten years) it is difficult to discern the specific transitions over short time, and the probable causal mechanisms. As such it is likely that certain land cover changes such as grasslands could transition so rapidly that it is not possible to establish the direction of the transition. This presents a key limitation in this study.

Although cropland had a general increase, this needs to be managed at sustainable levels. This underscores the need to clearly understand the drivers of the change that may include population pressure and the need for food and income. The change in land cover has implications on soil and water degradation, and sustainable production of food, timber and other essential products. There is need to intensify agricultural production under a scheme of optimal land use, by applying sustainable land use practices such as agroforestry and establishment of woodlots that limit impacts but assure continued economic returns to the farmers.

\section{Acknowledgements}

Authors would like to sincerely thank WWF Kenya, Astrium and National Aeronautics and Space Administration for the use of satellite images. Much thanks to Google for the maps and ESRI for the analytical software used. Authors would also like to thank Mr. Zachary Maritim and Mr. Liya Mango for the support provided during the initial conception and delineation of the study area. 


\section{References}

[1] Ramankutty, N., and Foley, J. A. 1999. "Estimating Historical Changes in Global Land Cover: Croplands from 1700 to 1992." Global Biogeochemical Cycles 13 (4): 997-1027.

[2] Foley, J. A., DeFries, R., Asner, G. P., Barford, C., Bonan, G., Carpenter, S. R., et al. 2005. "Global Consequences of Land Use." Science 309: 570-4. doi:10.1126/science.1111772.

[3] Food and Agriculture Organization. 2011. State of the World's Forests 2011. Rome: Food and Agriculture Organization of the United Nations.

[4] Meyfroidt, P., Rudel. , T. K., and Lambin, E. F. 2010. "Forest Transitions, Trade, and the Global Displacement of Land Use." PNAS 107 (49): 20917-22. doi:10.1073/pnas.1014773107.

[5] Albert, C., and Vargas-Moreno, J. C. 2010. "Planning-Based Approaches for Supporting Sustainable Landscape Development." Landscape Online 19: 1-9. doi:10.3097/LO.201019.

[6] World Bank Group. 2016. Data: Kenya. The World Bank Group. Accessed 5 June, 2018. http://data.worldbank. org/indicator/AG.LND.TOTL.K2?locations=KE.

[7] Government of Kenya. 2013. "Analysis of Drivers and Underlying Causes of Forest Cover Change in Various Forest Types of Kenya." Ministry of Forestry and Wildlife.

[8] Arwa, D. O. 2001. "GIS Based Rainfall-Runoff Model for the Turasha Sub-Catchment Kenya." Master thesis, International Institute for Geo-Information Science and Earth Science.

[9] Sombroek, W. G., Braun, H. M., and van der Pouw, B. J. 1980. The Explanatory Soil Map and Agro-Climatic Zone Map of Kenya. Report No. EI. Scale 1:1,000,000. Nairobi: Kenya Soil Survey. Accessed 12 September, 2013. https://library.wur.nl/isric/fulltext/.

[10] Nagelhout, A. 2001. "Performance Analysis of Small Format Aerial Photography (SFAP) in Assessing Current Status and Trends in Wind Erosion: A Case Study in the Longonot-Kijabe Hill Area, Naivasha District, Kenya." MSc thesis, International Institute for Aerial Survey and Earth Sciences.

[11] Kiai, S. P., and Mailu, G. M. 1998. Wetland Classification for Agricultural Development in Eastern and Southern Africa. Harare, Zimbabwe: Food and Agriculture Organization of the United Nations. Accessed 16, December, 2016. http://www.fao.org/docrep/003/x6611e/x6611e00.htm.

[12] Hennemann, R. 2001. Elective on Land Degradation, Assessment, Monitoring and Modelling. Enschede, The Netherlands: Soil Science Division, ITC.
[13] Muthuwatta, P. L. 2004. Long Term Rainfall-Runoff-Lake Level Modeling of the Naivasha Basin, Kenya. Enschede: ITC.

[14] NASA. 2015. Landsat Missions: Orthorectified Archives. US Department of the Interior. United States Geological Survey. Accessed 17 December, 2016. http://landsat.usgs.gov.

[15] ERDAS, Inc. 2008. IMAGINE DeltaCue User's Guide. Norcross, GA 30092-2500, USA: ERDAS, Inc. Accessed 28 March, 2017. http://web.pdx.edu/.

[16] Barazzetti, L., Scalioni, M., and Gianinetto, M. 2014. "Automatic Co-registration of Satellite Time Series via Least Squares Adjustment." European Journal of Remote Sensing 57: 55-74. doi:10.5721/EuJRS20144705.

[17] İlsever, M., and Unsalan, C. 2012. "Chapter 2. SpringerBriefs in Computer Science." In Two-Dimensional Change Detection Methods: Remote Sensing Applications. doi:10.1007/978-1-4471-42.

[18] Pal, N. R., and Pal, S. K. 1993. "A Review on Image Segmentation Techniques.” Pattern Recognition 26 (9): 1274-94.

[19] Dey, V., Zghang, Y., and Zhong, M. 2010. "A Review of Image Segmentation Techniques with Remote Sensing Perspective." In ISPRS TC VII Symposium-100 Years ISPRS, Vienna, Austria, edited by W. Wagner, and B. Székey, July 5-7 2010, IAPRS, XXXVIII, Part 7A, Vienna: ISPRS, pp. 31-42. Accessed 28 March, 2017. http://www.isprs.org/proceedings.

[20] Telgad, R., Siddiqui, A. M., and Deshmukh, P. D. 2014. "Fingerprint Image Segmentation Using Global Thresholding." International Journal of Current Engineering and Technology 4 (1): 216-9. Accessed 28 March, 2015 http://inpressco.com/wp-content/uploads/2014/02/Paper3 9216-219.pdf.

[21] Abubaker, H. M., Elhag, A. M., and Salih, A. M. 2013. "Accuracy Assessment of Land Use and Land Cover Classification (LU/LC) 'Case Study of Shomadi Area-Renk County-Upper Nile State, South Sudan'.” International Journal of Scientific and Research Publications 3 (5): 1-6.

[22] Congalton, R. G. 1991. "A Review of Assessing the Accuracy of Classifications of Remotely Sensed Data." Remote Sensing Environment 35: 35-46.

[23] Anderson, J. R., Hardy, E. E., Roach, J. T., and Witmer, R. E. 1976. A Land Use and Landcover Classification System for Use with Remote Sensor Data: Geological Survey Professional Paper 964. Washington: United States Department of the Interior. Accessed 13 May, 2013. https://pubs.usgs.gov/pp/0964/report.pdf.

[24] Puyravaud, J. P. 2003. "Standardizing the Calculation of the Annual Rate of Deforestation." Forest Ecology and Management 177: 593-6. doi: 
http://dx.doi.org/10.1016/S0378-1127(02)00335-3.

[25] Rouse, J. W., Haas, R. H., Schell, J. A., and Deering, D. W. 1973. "Monitoring Vegetation Systems in the Great Plains with ERTS." Third ERTS Symposium, NASA SP-351 I, pp. 309-17.

[26] NASA. 2015. United States Geological Survey. Accessed 17 December, 2016. http://Landsat.glovis.usgs.gov.

[27] Hailemariam, S. N., Soromessa, T., and Teketay, D. 2016. "Land Use and Land Cover Change in the Bale Mountain Eco-Region of Ethiopia during 1985 to 2015." Land 5: 1-22. doi:10.3390/land5040041.

[28] Mallupattu, P. K., and Reddy, J. R. 2013. "Analysis of Land Use/Land Cover Changes Using Remote Sensing Data and GIS at an Urban Area, Tirupati, India." The Scientific World Journal, 1-6. doi:http://dx.doi.org/10.1155/2013/268623.

[29] Coomes, O. T., Takasaki, Y., and Rhemtulla. 2016. "Forests as Landscapes of Social Inequality: Tropical Forest Cover and Land Distribution among Shifting Cultivators." Ecology and Society 21 (3): 20.

[30] Ouedraogo, I., Mbow, C., Balinga, M., and Neufeldt, H. 2015. "Transitions in Land Use Architecture under Multiple Human Driving Forces in a Semi-Arid Zone." Land 4: 560-77.

[31] Weyer, W. D., Granger, J. E., Hill, T. R., and O'Connor, T. G. 2015. "Land Transformation and Its Implication for Biodiversity Integrity and Hydrological Functioning from 1944 to 1999, Karkloof Catchment, South Africa." Bothalia $\quad 45 \quad$ (1): $\quad 1-13 . \quad$ doi: dx.doi.org/10.4102/abc.v45i1.1907.

[32] Were, K. O. 2008. "Monitoring Spatio-Temporal Dynamics of Land Cover Changes in Lake Naivasha Drainage Basin, Kenya." Master thesis, International Institute for Geo-Information Science and Earth Observation. Accessed 17 August, 2016. ftp://ftp.itc.nl/pub/naivasha/ITC/Were2008.pdf.

[33] Onywere, S. M., Mironga, J. M., and Simiyu, I. 2012. "Use of Remote Sensing Data in Evaluating the Extent of Anthropogenic Activities and Their Impact on Lake Naivasha, Kenya." The Open Environmental Engineering Journal 5: 9-18.

[34] Yacouba, D., Hu, G. D., and Wen, X. P. 2010. "Assessment of Landuse Cover Changes Using NDVI and DEM in Puer and Simao Counties, Yunnan Province." World Rural Observations 1 (2): 1-11.
[35] Hyandye, C., Mandara, S. G., and Safari, J. 2015. "GIS and Logit Regression Model Applications in Land Use/Land Cover Change and Distribution in Usangu Catchment." American Journal of Remote Sensing 3 (1): 6-16. doi:10.11648/j.ajrs.20150301.12.

[36] Boundeth, S., Nanseki, T., Takeuchi, S., and Satho, T. 2012. "Land Use Change and Its Determinant Factors in Northern Laos: Spatial and Socio-Economic Analysis." Journal of Agricultural Science 4 (12): 190-204.

[37] Braimoh, A. K., and Vlek, P. L. G. 2004. "Scale-Dependent Relationships between Land-Use Change and Its Determinants in the Volta Basin of Ghana." Earth Interactions 8 (4): 1-23.

[38] Petit, C., Scudder, T., and Lambin, E. 2001. "Quantifying Processes of Land-Cover Change by Remote Sensing: Resettlement and Rapid Land-Cover Changes in South-Eastern Zambia.” Int. J. Remote Sensing 22 (17): 3435-56.

[39] Bayramov, E., Buchroithner, M., and Bayramov, R. 2016. "Quantitative Assessment of 2014-2015 Land-Cover Changes in Azerbaijan Using Object-Based Classification of LANDSAT-8 Time Series." Modeling Earth Systems and Environment 2 (35): 1-13. doi: 10.1007/s40808-016-0088-8.

[40] Rawat, J. S., and Kumar, M. 2015. "Monitoring Land Use/Cover Change Using Remote Sensing and GIS Techniques: A Case Study of Hawalbagh Block, District Almora, Uttarakhand, India." The Egyptian Journal of Remote Sensing and Space Sciences 18 (1): 77-84. doi: https://doi.org/10.1016/j.ejrs.2015.02.002.

[41] Wanyonyi, R. W. 2012. "Impact of Human Population on Land Degradation in Former Lugari District, Kakamega County, Kenya." Unpublished Master of Environmental Sciences Thesis, Nairobi: Kenyatta University.

[42] Zacharia, M., Ako, E., Kiplagat, J., Maingi, S., and Olang, L. O. 2013. "Assessment of Landcover Changes in Lake Olbolosat Region of the Central Kenyan Highlands Using Landsat Satellite Imagery Aided by Indigenous Knowledge." Journal of Biodiversity Management and $\begin{array}{lllll}\text { Forestry } & 2 & \text { (2): } & 1-5 . & \text { doi: }\end{array}$ http://dx.doi.org/10.4172/2327-4417.1000107.

[43] Kinyanjui, M. J. 2011. "NDVI-Based Vegetation Monitoring in Mau Forest Complex, Kenya." African Journal of Ecology 49 (2): 165-74. doi:10.1111/j.1365-2028.2010.01251.x. 